\section{The Bureaucratic Structure} Hypothesis

\author{
Juliana Abagsonema Abane ${ }^{1}$ and \\ Ernest Yeboah Asamoa ${ }^{2}$ \\ ${ }^{1}$ Department of Management Studies, University \\ of Mines and Technology, Tarkwa, Ghana \\ ${ }^{2}$ Rising Sun Montessori School, Sakunmono, \\ Accra, Ghana
}

\section{Synonyms}

Bureaucratic principles; Bureaucratic structure; Ideal bureaucracy; Legal-rational; Organizational structure; Weberian bureaucracy

\section{Definition}

The ideal bureaucracy is hypothesized by Max Weber to lead to efficiency and effectiveness in organizations. Max Weber proposes the concept of bureaucracy in a context in which he considers rationalization of society as inevitable (Pollitt 2008), causing a growing impersonality in the social relationship, disenchantment of the world. However, a possible downside of this rationalitydriven world is the creation of an "iron cage," trapping man in a mundane, routinized environment (Rønningstad 2015, p. 5).

The bureaucratic structure hypothesis is the link between the six main principles of the ideal model to organizational effectiveness and performance. Max Weber believed that proper structuring of an organization with the core principles of bureaucracy, formalization, centralization, and authority or hierarchy would give organization leadership a sense of direction and control.

\section{Introduction}

Wilson (1975) and Samier (2013, p. 901) observe that the term "bureaucracy" means many things to different people. This may lead to what has been termed as "the bureaucracy problem" (Wilson 1975). To Wilson:

\section{Max Weber, after all, warned us that in capitalist and socialist societies alike, bureaucracy was likely to acquire an "overpowering" power position. Con- servatives have always feared bureaucracy, save perhaps the police. Humane socialists have fre- quently been embarrassed by their inability to rec- oncile a desire for public control of the economy with the suspicion that a public bureaucracy may be as immune to democratic control as a private one.}

Samier (2013, p. 904) provides a very important observation. Max Weber who seems to be one of the most important proponents of bureaucracy seemed also to be one of its greatest critics. According to Samier, Max Weber (1930) saw that the emphasis on legal-rational values and thinking "would create people and organizations that would lose connection with other values such as affect, tradition, and higher-order values, 
leading to disenchantment, and an iron cage of modernity." Similarly, Serpa and Ferreira (2019, p. 12) argue that bureaucracy, in general, is associated with very negative features of organizations, such as delays in operation, action centered on opaque standards, excessive requests for documentation, or even countless difficulties in meeting users' or customers' requests. Four themes are explored in the remainder of the entry.

\section{The Bureaucratic Structure}

Robertson (2004, p. 46) defines bureaucracy as a way of organizing human institutions to ensure impersonal effectiveness. To achieve this, a hierarchical structure is adopted; this structure has the shape of a pyramid with authority emanating from top to down. Rønningstad (2015, p. 4) asserts strongly that hierarchy and defined structure are assets for bureaucratic organizations, making them coordinated and precise, while minimizing unnecessary use of resources is key to organizational effectiveness.

Stevenson (1986, p. 308) posits that the use of structure has become necessary in recent times as a result of limitations and failings of individuals and not for the subordination and control of employees. Six characteristics can be understood as structural ideal types facilitating a rational organization with a focus on hierarchy, formalization, rules, structuring, and regular activities (Rønningstad 2015, p. 5).

Furthermore, hierarchical organization and line management are seen as key to solving problems of accountability. The hierarchical structure was adopted to maintain the conceptualization of bureaucrats as subservient agents.

\section{Theoretical Approach of the Bureaucratic Structure Hypothesis}

Grdešić (2016, p. 787) defines bureaucracy as "the class of professional managers" but also "the system of social and political relations in which the main role is played by the bureaucracy," as well as the "type of activity of the bureaucracy itself"
(Grdešić 2016, p. 787). Bureaucracy is a selforganizing entity, and thus, bureaucrats who are self-sufficient, secure, and psychologically developed understand that intangible liberty comes before tangible freedom. To feel further liberated, not because there is an inadequacy but because it makes for personal happiness, this bureaucrat would be likely to employ non-corrupt intentions (Imam 2014).

\section{The Rational Approach}

Selznick (1943, p. 50) and Hilbert (1987, p. 70) support the rational approach of Weber to structuring in organizations. Weber's main interest was in the development of rational bureaucratic behavior as a break from the ties of seignorial leadership setup under the feudal system. A Weberian approach more likely treats bureaucracy as a belief in the rationality of organized action than as a macro-entity that empirically displays that rationality for sociology. Legal-rational authority follows formalized rational rules, procedures, and laws as the basis for transforming modern organizations.

Furthermore, it assumes that actual bureaucratic behavior never conforms with the bureaucratic model, not only because the model is an ideal type but also because it is a subjective type. In tune with this assertion, Rønningstad (2015, p. 5) quotes Weber in the following:

This system based on the rationality of instructions
illustrates how the instrument of bureaucracy can be
used for good or bad; the bureaucracy is dependent
on good instructions to do good work, just like a
hammer is dependent on a steady hand not to hurt
the thumb. This is not to say that this is the best
system for society, but is the best system for getting
things done, and it is prevalent because it is the most
rational way of organizing. Instead of an organiza-
tion being ruled by a dominant master, it is ruled by
rationality, and the bureaucratic organization is the
best vehicle for delivering this rationality. (Weber
1991)

Bureaucracy is the most typical example of legal domination. This can be attributed to the fact that bureaucrats are rational agents, willing, and able to act in their interests (Serpa and Ferreira 
2019 , p. 14). However, the approach has its limitations. The limitations include (1) exploitative tendencies of bureaucrats because of information asymmetry; (2) multi-principal problem may emerge where bureaucrats ignore voices of reason and listen to self-interested elected officials; (3) the approach assumes actors are responsive without recognizing that bureaucracies are not monolithic and contain a wide range of values; and (4) public bureaucracies can increase the hierarchical structure which may complicate goals (Serpa and Ferreira 2019, p. 14; Stevenson 1986, p. 308).

\section{The Bureaucratic Hypotheses}

Six main hypotheses can be related to bureaucracy. A hypothesis is just an educational guess, which predicts the outcome of a phenomenon or an event. These hypotheses are drawn from six principles spelled out by Weber in his ideal bureaucracy. The motive is that these principles if adhered to by bureaucrats will lead to greater efficiency and effectiveness (Serpa and Ferreira 2019 , p. 15). However, these hypotheses are not the Holy Grail. They have underlying deficiencies which are discussed with each hypothesis.

The first hypothesis is that a planned division of labor leads to effectiveness and efficiency. To effect the division of labor, regular tasks are assigned as official duties, the authority to command others is distributed stably and is strictly determined by rules about coercion, and provision is made for the regular and continuous fulfillment of task (Haveman and Klutz 2016, p. 1). The difficulty with this hypothesis arises when a strict division of labor overlooks the ability and creativity of the bureaucrats to innovate. Some bureaucrats can multitask effectively and efficiently which in the end can help reduce cost and enhance the effectiveness and efficiency of the bureaucratic system. However, a division of labor would not allow them to multitask or even overlap their functions in exigencies.

The second hypothesis is a hierarchy of authority in which power and information flow from top to bottom will enhance the efficient operations of an organization. This requires an established system of superordination and subordination. The hierarchy culminates with a single bureaucrat at the top; it is thus a "mono-critical" structure (Haveman and Klutz 2016, p. 1). The hierarchical structure only functions in simple, mechanistic, and closed systems. Systems, which are complex and open, will be ineffective as hierarchical structure fails to take into account the importance of informal organizations within formal organizations. Samier (2013, p. 904) critiques that bureaucracy maintains the class structure.

The third hypothesis is that formalization and documentation are closely linked to the efficiency and effectiveness of the use of organizational resources. The formalization of rules, regulations, and procedures demands bureaucrats to document each work process without using personal discretion in the discharge of their duties. Thus, bureaucrats are therefore required to be functionally upright rather than personally involved in their positions. In effect, the principles of "impersonal of interpersonal" relations must be seen to be operating. Another example could be the hiring and promotion practices of organizations must be explicit without any form of ambiguity. This hypothesis similarly leads to the emphasis on paperwork to the neglect of "pragmatic solutions" and innovation because everything in this bureaucratic structure is rule-bound and does not necessarily lead to effectiveness. As a result, this type of structure is time-consuming, higher costs and more efforts are the major output of the system, of which the product is red-tapism.

The fourth hypothesis is that selection of bureaucrats based on qualification and competency makes the bureaucracy efficient. Task performance is characterized by specialization in training. Performing their jobs competently requires bureaucrats to possess specialized knowledge and skills, which in turn requires specialized training or education, certified by passing special exams. However, the emphasis on qualification based on specific examination downplays talent. Nonetheless, there are many organizations, for instance, Ernst and Young Auditing firm, that employ talents without certification and such people excel in their task performance. Here talent 
rather than qualification is used in selecting competent employees.

The fifth hypothesis is that job tenure or security of employment will retain institutional memory, which will provide stability in organizational effectiveness. Consequently, bureaucrats use all their time and energy to undertake tasks related to the bureaucracy, and they will be committed to the organization's health and performance due to job security. Haveman and Klutz (2016, p. 1) observed that bureaucrats are expected to devote time to work to protect the public interest while subordinating their interest. The emergence of performance-based contracts and agreements signifies that this hypothesis will not always be fit for ensuring effectiveness and efficiency in an organization either in the public bureaucratic system or in private organizations.

The sixth hypothesis is that managementbased centralization of authority brings efficiency and effectiveness. Decision-making emanates from the top management structure to the lower parts of the structure. Management decisions are based on rules and instructions resulting from specialized knowledge in the vertical relationship provided by the bureaucratic structure. However, this stalls innovation and creativity in organizations because lower-level officers have little input into decisions and policies that affect their task performance. This may lead to inefficiency since coordination is sometimes difficult to undertake in very large organizations. Although there is horizontal decentralization within a bureaucratic structure, the presence of differentiation on functions and departments may slow decision-making in emergencies.

Meier and Compton (2017, p. 1) believe that bureaucracies have developed fewer structures of hierarchy, networks, clear goals, and privatization. Also, bureaucracies play a representative role; however, when they face challenges in material resources, representation of minority interests, and loss of public trust, they become affected. Stevenson (1986, p. 308) agreed that formal structures are created, maintained, and eliminated in the name of the efficient accomplishment of organizational goals. Thus, organizational goals need to be spelled out clearly always.
However, bureaucratic "failures" of efficiency, effectiveness, or responsiveness can also be linked to lack of adequate resources, ambiguous goals, and lack of autonomy to exploit comparative informational advantages (Meier and Compton 2017, p. 4).

\section{Functions of the Bureaucratic Structure Hypothesis}

The bureaucratic hypotheses function in several ways. Firstly, a division of labor ensures that there exists as part of the bureaucracy a human resource focused on specific tasks and is capable of delivering the policy goals and outcomes of the system. The ability to deliver goals makes the system effective and efficient.

Secondly, Labolo (2013, p. 166) asserts that a hierarchical system is needed to get the most out of the flow of power in society which is the ultimate goal. This signifies that goals are set by those in authority at the top, while implementation is done by those below the hierarchy, leading to organizational effectiveness.

Thirdly, formal documentation functions as the memory of the bureaucratic system. This ensures that records and systems for keeping data and information are well developed. This also enhances impersonality, which could lead to social justice. There is also a reduction in corruption because of clear records and procedures.

Fourthly, the selection of bureaucrats based on specialized skills and technical skills brings greater goal attainment and efficiency. This ensures that people who possess certain abilities occupy certain parts of the system, which promotes professionalism as well.

Fifthly, the other function of the bureaucratic hypothesis is that of unparalleled commitment. This is derived from the hypothesis that full-time employment and job security can improve organizational performance. This can be achieved when remuneration and incentives are provided to bureaucrats to make them focus entirely on their tasks.

Sixthly, there is clarity in standard procedures and it limits the use of discretion. The 
documentation and writing down of rules ensure that effectiveness and efficiency are achieved by decreasing ambiguity and conflict of rules, regulations, and bureaucratic pronouncements.

\section{Conclusion}

Weber (1947) developed six main hypotheses to provide an understanding of how organizations could be structured to ensure the efficient and effective use of resources. As a result, the bureaucratic structure emerges as an ideal model in most organizational forms, especially in the public domain. Although the hypothesis has provided insight into the effectiveness of organizations, it provides little room for how organizations could be creative and innovative in times of rapid change. Consequently, the bureaucratic structure provided by Weber can only be effective and efficient in a stable environment since it is mechanistic in its outlook and implementation, thereby making its application very rigid and rule-bound. However, the hypothesis is deficient because, in highly turbulent times such as the emergence of the COVID-19 pandemic, nations and institutions have failed to adhere to strict bureaucratic principles by becoming more flexible in the flow of work and reporting systems.

\section{Cross-References}

Bureaucracy and Order
Bureaucracy and Stability
Bureaucratic Instrumentality
- Bureaucratic Machine
- Bureaucratic Paradigm as Myth
- Bureaucratic Responsibility
- Bureaucratic Rule-Making
- Structure of Bureaucratic Decisions

\section{References}

Grdešić M (2016) Serbia's anti-bureaucratic revolution as manipulation? A cultural alternative to the elite-centric approach. Comp Stud Soc Hist 58(3):774-803. https:// doi.org/10.1017/S0010417516000359

Haveman HA, Klutz D (2016) Bureaucracy. Palgrave Macmillan, London. https://doi.org/10.1057/978-1-34994848-2 534-1

Hilbert AR (1987) Bureaucracy as belief, rationalization as repair: Max Weber in a post-functionalist age. Sociol Theory 5(1):70-86

Imam A (2014) Non-corrupt intention in absolute liberty: deductive inference from a freedom and liberty-driven culture of corruption in a hypothetical bureaucracy. Adm Theory Praxis 36:125-132. https://doi.org/ $10.1080 / 10841806$

Labolo M (2013) Characteristic of Weber bureaucracy and its relevance in Indonesia. Asian Soc Sci 9(2). https:// doi.org/10.5539/ass.v92p163

Meier KJ, Compton EM (2017) Bureaucracy to postbureaucracy: the consequences of political failures. In: Oxford research encyclopedia of business and management. Oxford University Press, Oxford

Pollitt C (2008) Bureaucracies remember, postbureaucratic organizations forget? Public Adm 87(2):198-218. https://doi.org/10.1111/j.14679299.2008.01738.x

Robertson D (2004) The Routledge Dictionary of Politics, 3rd Ed, p.46. London: Routledge

Rønningstad CA (2015) Finding bureaucracy: are managers in public administrations more bureaucratic in their attitudes toward structure and values than managers in private enterprises? The University of Oslo, Oslo. http://www.duo.uio.no/

Samier EA (2013) Bureaucratic theory: myths, theories, models, critiques. In: Brown G, Lara-Alecio R, Irby BJ (eds) Handbook of educational theories. Information Age Publishing, Charlotte

Selznick P (1943) An approach to a theory of bureaucracy. Am Sociol Rev 8(1):47-54

Serpa S, Ferreira MC (2019) The concept of bureaucracy by Max Weber. Int J Soc Sci Stud 7(2):12-18. https:// doi.org/10.11114/ijsss.v7i2.3979

Stevenson WB (1986) Change in the structure of bureaucracy: a longitudinal analysis. Sociol Perspect 29(3):307-336

Weber M (1930) The Protestant Ethic and the Spirit of Capitalism. London: Unwin Hyman

Weber M (1947) The theory of economic and social organizations (trans: Henderson AM, Parsons T, ed: Parsons T). Oxford University Press, Oxford

Weber M (1991) From Max Weber: essays in sociology. Routledge, London

Wilson QJ (1975) The bureaucracy problem. Public Interest 41:77-103 